\title{
Normal expiratory flow rate and lung volumes in patients with combined emphysema and interstitial lung disease: A case series and literature review
}

\author{
Karen L Heathcote MD FRCPC ${ }^{1}$, Donald W Cockcroft MD FRCPC ${ }^{1}$, \\ Derek A Fladeland MD FRCPC ${ }^{2}$, Mark E Fenton MD FRCPC ${ }^{1}$
}

\begin{abstract}
KL Heathcote, DW Cockcroft, DA Fladeland, ME Fenton. Normal expiratory flow rate and lung volumes in patients with combined emphysema and interstitial lung disease: A case series and literature review. Can Respir J 2011;18(5):e73-e76.

Pulmonary function tests in patients with idiopathic pulmonary fibrosis characteristically show a restrictive pattern including small lung volumes and increased expiratory flow rates resulting from a reduction in pulmonary compliance due to diffuse fibrosis. Conversely, an obstructive pattern with hyperinflation results in emphysema by loss of elastic recoil, expiratory collapse of the peripheral airways and air trapping. When the diseases coexist, pulmonary volumes are compensated, and a smaller than expected reduction or even normal lung volumes can be found. The present report describes 10 patients with progressive breathlessness, three of whom experienced severe limitation in their quality of life. All patients showed lung interstitial involvement and emphysema on computed tomography scan of the chest. The 10 patients showed normal spirometry and lung volumes with severe compromise of gas exchange. Normal lung volumes do not exclude diagnosis of idiopathic pulmonary fibrosis in patients with concomitant emphysema. The relatively preserved lung volumes may underestimate the severity of idiopathic pulmonary fibrosis and attenuate its effects on lung function parameters.
\end{abstract}

Key Words: Emphysema; Expiratory flow rates; Intersitial lung disease; Lung volumes

\section{CASE PRESENTATION}

A 49-year-old truck driver was referred to the respirology outpatient clinic of the Royal University Hospital (Saskatoon, Saskatchewan) for evaluation of an abnormal immigration chest radiograph. He was trying to emigrate from England (United Kingdom) to Canada. At the time of referral, he denied any symptomatology, but over the ensuing two months developed progressive dyspnea and nonproductive cough. Although he was a truck driver at the time of initial presentation, he previously worked in a limestone quarry for eight years. He denied any other occupational or environmental exposures. He was a current cigarette smoker with a 35 pack-year history. His medical history was also significant for hypertension, dyslipidemia and impaired fasting glucose.

His room air saturations during the first clinic visit were $94 \%$ to $96 \%$. Posterior breath sounds had fine inspiratory crackles at the bases, with no wheeze. Anterior breath sounds were clear. There was marked clubbing. There were no clinical signs of right-sided heart failure; the remainder of the examination was unremarkable.

Laboratory investigation revealed polycythemia (hemoglobin $179 \mathrm{~g} / \mathrm{L}$ ) and mild elevation of hepatocellular and cholestatic liver enzyme levels (aspartate transaminase $53 \mathrm{U} / \mathrm{L}$, alanine transaminase $91 \mathrm{U} / \mathrm{L}$ and gamma-gutamyl transferase $84 \mathrm{U} / \mathrm{L}$ ). C-reactive protein (CRP) and erythrocyte sedimentation rate (ESR) were both normal. The initial chest radiograph (Figure 1) revealed coarse reticular markings in the mid to lower lung zone, with no evidence of honeycomb cyst formation. Lung volumes were preserved. The initial pulmonary function test revealed normal spirometry and lung volumes, with a

\author{
Le débit expiratoire normal et les volumes \\ pulmonaires chez les patients atteints à la fois \\ d'emphysème et de maladie pulmonaire interstitielle : \\ une série de cas et une analyse bibliographique
}

\begin{abstract}
L'exploration fonctionnelle respiratoire chez les patients présentant une fibrose pulmonaire idiopathique se caractérise par un profil restrictif incluant de petits volumes pulmonaires et un débit expiratoire accru découlant d'une réduction de la compliance pulmonaire causée par une fibrose diffuse. Par contre, un profil obstructif à l'hyperinflation entraîne un emphysème causé par la perte du retour élastique, le collapsus respiratoire des voies aériennes périphériques et le trappage. En cas de coexistence de ces pathologies, les volumes pulmonaires sont compensés et on constate des volumes pulmonaires moins limités que prévu ou même normaux. Le présent rapport décrit le cas de dix patients ayant un essoufflement progressif, dont trois qui présentaient une grave limite à leur qualité de vie. Tous les patients avaient une atteinte interstitielle pulmonaire et un emphysème à la tomodensitométrie pulmonaire. Ils avaient une spirométrie et des volumes pulmonaires normaux, accompagnés d'une grave atteinte de l'échange gazeux. Des volumes pulmonaires normaux n'excluent pas un diagnostic de fibrose pulmonaire idiopathique chez les patients ayant un emphysème concomitant. En raison des volumes pulmonaires relativement préservés, on peut sous-estimer la gravité de la fibrose pulmonaire idiopathique et en atténuer les effets sur les paramètres de la fonction pulmonaire.
\end{abstract}

markedly reduced diffusing capacity (Figure 2). A high-resolution computed tomography (CT) scan of the chest revealed interstitial fibrosis with some honeycombing and subpleural cystic changes consistent with idiopathic pulmonary fibrosis (IPF) and diffuse emphysematous changes (Figure 3). Left and right heart catheterization revealed normal coronary arteries with normal left ventricular function, and moderate to severe pulmonary hypertension $(\mathrm{PH})$ with a mean pulmonary artery pressure of $40 \mathrm{mmHg}$. Pulmonary capillary wedge pressure was $23 / 18 \mathrm{mmHg}(14)$.

The patient's dyspnea progressed rapidly. He was referred to thoracic surgery for consideration of lung biopsy to confirm a diagnosis, but the surgeon believed that the risk was too great. Trials of medical management, including high-dose corticosteroids, proved to be of no benefit. The patient was offered the option of referral to a transplant centre for assessment for heart-lung transplant, but he declined. He passed away from respiratory failure four months after initial assessment.

This individual was one of a series of 10 patients who we reviewed at the Royal University Hospital who had a combination of emphysema and interstitial lung disease, one of whom (patient 8 [Table 1]) has been previously reported (1). The characteristics of these patients are shown in Table 1. Chest radiograph and chest CT in all patients demonstrated emphysematous changes and interstitial lung disease. Nine of these had presumed IPF based on history and classic high resolution CT scan, and the 10th (patient 8 ) had (reversible) amiodarone lung. Pulmonary function tests for all 10 patients are shown in Table 2, while chest imaging results are shown in Table 3. All patients

${ }^{1}$ Division of Respirology, Department of Medicine, Royal University Hospital; ${ }^{2}$ Department of Radiology, University of Saskatchewan, Saskatoon, Saskatchewan

Correspondence: Dr Mark E Fenton, Division of Respirology, Critical Care and Sleep Medicine, Royal University Hospital, 103 Hospital Drive, Saskatoon, Saskatchewan S7N OW8. Telephone 306-966-8274, fax 306-966-8694, e-mail mark.fenton@usask.ca 


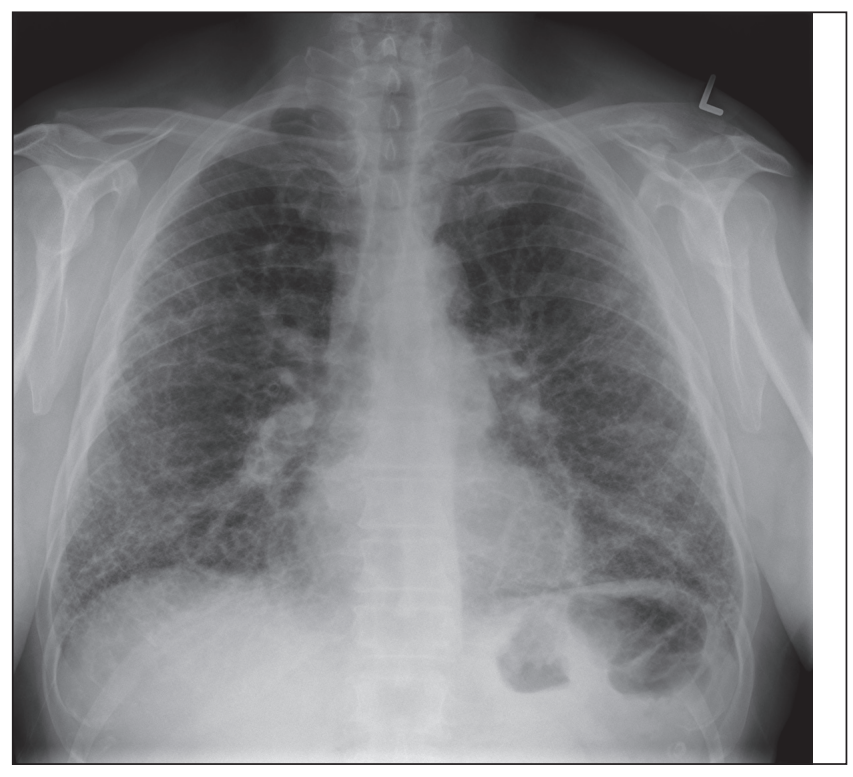

Figure 1) Initial chest radiograph of the index case. Peripheral and basilar coarse interstitial markings. Preserved lung volumes suggest underlying emphysema. Also note the the prominent pulmonary artery. Subsequent right heart catheterization revealed a mean pulmonary artery pressure of $40 \mathrm{mmHg}$

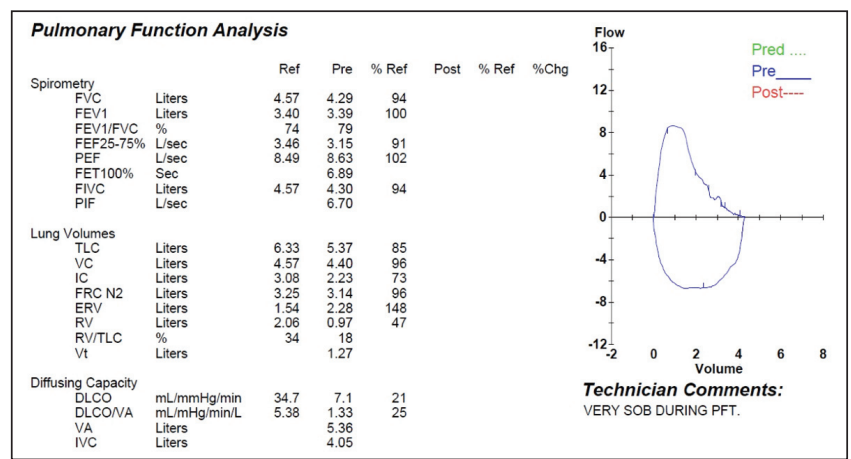

Figure 2) Pulmonary function results of the index case. Chg Change; DLCO Diffusing capacity for carbon monoxide; ERV Expiratory reserve volume; FEF25-75\% Forced expiratory flow between 25\% and 75\% of forced vital capacity (FVC); FET Forced expiratory time; FEV1 Forced expiratory volume in $1 \mathrm{~s}$; FIVC Forced inspiratory vital capacity; FRC N2 Functional residual capacity by nitrogen; IC Inspiratory capacity; IVC Inspiratory vital capacity; PEF Peak expiratory flow; PFT Pulmonary function test; PIF Peak inspiratory flow; Pred Predicted; Ref Reference; RV Residual volume; SOB Short of breath; TLC Total lung capacity; VA Alveolar volume; VC Vital capacity; Vt Tidal volume

received treatment for their obstructive lung disease with inhaled bronchodilators, and three patients received corticosteroids for their restrictive lung disease. No patients received further immunosuppression or immune modulating agents beyond corticosteroids. Four patients required supplemental oxygen therapy during their follow-up. None of these patients demonstrated improvement of their interstitial lung disease while taking corticosteroids. Five of these patients have since passed away from progressive respiratory failure, with a mean survival of 23 months from first assessment. Interestingly, two of these patients had minimal dyspnea when first assessed (patients 5 and 7).

\section{DISCUSSION}

Patients with interstitial lung diseases (ILDs) characteristically develop increased static elastic recoil with resulting increase in flow rates. Lung volumes are typically reduced. A decline in diffusing capacity for

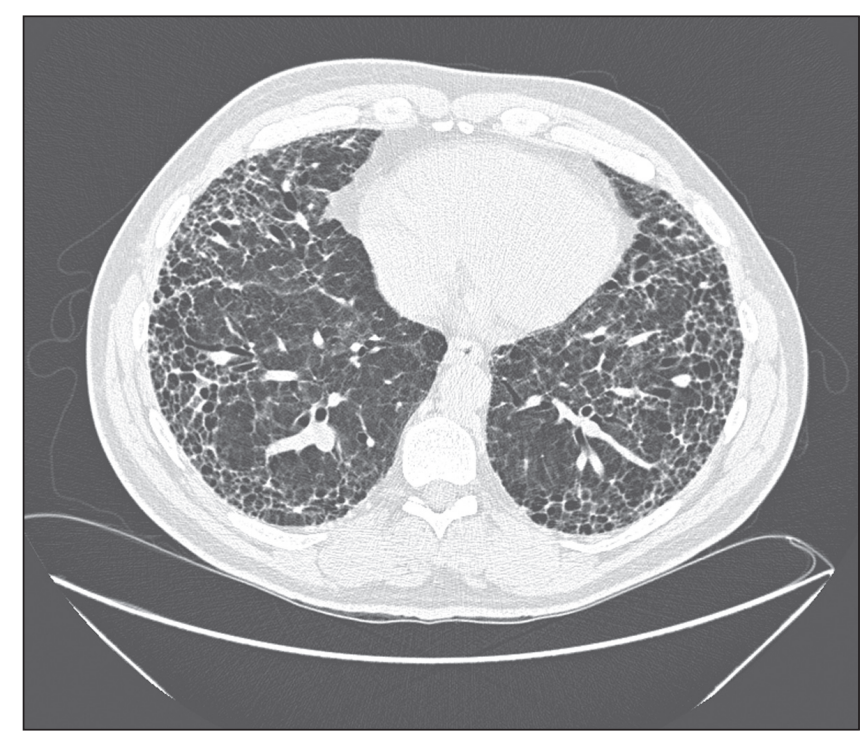

Figure 3) High-resolution chest computed tomography of the patient. Note the peripheral interstitial fibrosis and honeycombing, with superimposed centrilobular and paraseptal emphysema

TABLE 1

Characteristics of patients presenting with dyspnea related to interstitial lung disease and emphysema $(n=10)$

\begin{tabular}{|c|c|c|c|c|}
\hline Patient & $\begin{array}{l}\text { Sexl } \\
\text { age, } \\
\text { years }\end{array}$ & $\begin{array}{c}\text { Smoking, } \\
\text { pack-years }\end{array}$ & Symptoms & $\begin{array}{c}\text { MRC } \\
\text { Questionnaire }\end{array}$ \\
\hline $1 *$ & $\mathrm{M} / 50$ & 35 & Cough, exertional dyspnea & $\mathrm{V}$ \\
\hline $2^{\star}$ & M/85 & 40 & Dyspnea & III \\
\hline 3 & $\mathrm{M} / 79$ & 50 & Dyspnea & II \\
\hline 4 & M/66 & 5 & Exertional dyspnea, cough & II \\
\hline $5^{\star}$ & $\mathrm{F} / 74$ & 32 & Cough & I \\
\hline 6 & $\mathrm{M} / 69$ & 40 & Cough & I \\
\hline $7^{*}$ & $\mathrm{M} / 74$ & 40 & Cough & I \\
\hline $8^{*}$ & $\mathrm{M} / 77$ & 40 & Progressive dyspnea, cough & IV \\
\hline 9 & $\mathrm{~F} / 72$ & 40 & Exertional fatigue, weakness & IV \\
\hline 10 & $\mathrm{M} / 77$ & 70 & Exertional dyspnea & V \\
\hline
\end{tabular}

*Deceased. F Female; MRC Medical Research Council; M Male

carbon monixide (DLCO) occurs as a result of contraction of the pulmonary capillary volume and by ventilation and perfusion abnormalities, and may precede the reduction in lung volumes (2). In contrast, an emphysematous pattern is revealed on expiratory flow rates by a low forced expiratory volume in $1 \mathrm{~s} /$ forced vital capacity ratio, and is often associated with large lung volumes. This is a result of loss of elastic recoil and high lung compliance, expiratory collapse of the peripheral airways and air trapping. Because of the progressive destruction of alveolar structures, the DLCO is often reduced (3). When ILD and emphysema occur together, this can result in normalization of expiratory flow rates and lung volumes (1). In this instance, the DLCO is low due to effects of both processes. In our patients there was no clear correlation between the degree of diffusion impairment and degree of dyspnea.

In patients with dyspnea, an isolated reduction in DLCO is extremely rare $(<1 \%)$, and $22 \%$ of isolated low diffusing capacity is reported to be due to a combination of ILD and emphysema (4). Other causes of an isolated low diffusing capacity include pulmonary vascular disease, early interstitial lung disease, anemia and an increased carboxyhemoglobin level. Moreover, patients with nonpulmonary diseases such as diabetes mellitus, hypothyroidism and chronic renal failure, and those with environmental dust exposures can also exhibit isolated reductions in DLCO (5-8). Given the high 
TABLE 2

\section{Pulmonary function tests for patients presenting with dyspnea related to interstitial lung disease and emphysema $(n=10)^{*}$}

\begin{tabular}{lrrrrc}
\hline Patient & FEV $_{\mathbf{1}}$, L (\%) & FVC, L (\%) & FEV $_{\mathbf{1}}$ FVC & TLC, L (\%) & DLCO, \% \\
\hline $1^{\dagger}$ & $100(3.39)$ & $94(4.29)$ & 79 & $85(5.37)$ & 21 \\
$2^{\dagger}$ & $128(2.43)$ & $105(3.27)$ & 75 & $89(4.32)$ & 39 \\
3 & $120(2.95)$ & $99(3.80)$ & 78 & $102(6.01)$ & 50 \\
4 & $92(2.73)$ & $93(4.02)$ & 68 & $102(6.45)$ & 59 \\
$5^{\dagger}$ & $91(1.66)$ & $80(2.09)$ & 79 & $87(3.97)$ & 38 \\
6 & $114(3.29)$ & $94(4.01)$ & 82 & $98(6.18)$ & 48 \\
$7^{\dagger}$ & $152(4.13)$ & $135(5.60)$ & 74 & $112(6.95)$ & 49 \\
$8^{\dagger}$ & $88(1.99)$ & $92(3.15)$ & 65 & $97(5.06)$ & 25 \\
9 & $101(1.56)$ & $99(2.21)$ & 70 & $100(3.79)$ & 50 \\
10 & $114(2.89)$ & $99(3.86)$ & 75 & $99(5.69)$ & 39 \\
\hline
\end{tabular}

${ }^{*}$ Note the normal spirometry and lung volumes, with reduced diffusing capacity for carbon monoxide (DLCO); ${ }^{\dagger}$ Deceased. FEV ${ }_{1}$ Forced expiratory volume in $1 \mathrm{~s}$; FVC Forced vital capacity; TLC Total lung capacity

incidence of concurrent emphysema and interstitial lung disease, chest CT is of considerable value in the assessment of patients with an isolated diffusing defect (9).

Coincidental IPF and emphysema was first reported by Wiggins et al (9) who documented a series of eight patients in 1990. Since then, the syndrome of combined pulmonary fibrosis and emphysema (CPFE) has been increasingly recognized. The pathophysiology of CPFE is unclear. Tobacco smoking has been postulated to be a cause (10-12); other possible risk factors include sex (13), genetics and exposure to agrochemical compounds (14). The prevalence of emphysema in IPF patients is estimated to be nearly $30 \%$ (15). The syndrome of CPFE results from the association of distinct features, including severe dyspnea, tobacco smoking, spirometry findings, severely impaired transfer capacity for carbon monoxide, hypoxemia with exercise, characteristic imaging features and a high probability of severe $\mathrm{PH}$. The likelihood of development of $\mathrm{PH}$ is higher in patients with CPFE than in those with IPF without emphysema. The prognosis for patients with CPFE is worse than that for patients with nonemphysema IPF, and patients with CPFE who have concomitant $\mathrm{PH}$ have an even poorer prognosis (15). Furthermore, patients with CPFE may have a high prevalence of lung cancer (13).

Chest CT is the critical test in the diagnosis of combined ILD and emphysema. Spirometry and lung volumes can be misleading because they can normalize when the two processes coexist. A reduced DLCO is not specific for combined ILD and emphysema; a lung biopsy carries surgical risk, and some patients may be too sick to undergo this procedure safely. Chest CT is easily accessible, and all of our patients showed changes consistent with combined ILD and emphysema.

Patients with concurrent emphysema and ILD can present with normal expiratory flow rates and lung volumes, and a marked reduction in DLCO. The preserved lung volumes may underestimate the extent and progression of disease; another marker should be used to follow the clinical course of these patients. Potential surrogates are the presence of PH or the extent of reduction in DLCO (16). Normal spirometry and lung volumes do not rule out a diagnosis of emphysema or ILD in a patient in whom the two processes could coexist.

\section{CONCLUSIONS}

Emphysema and ILD produce opposing effects on expiratory flow rates and lung volumes on pulmonary function testing. However, both can cause reductions in the DLCO. Patients with concurrent emphysema and ILD can present with normal expiratory flow rates and lung volumes, and a marked reduction in DLCO. Isolated reduction in DLCO can often be explained by the association of emphysema with a restrictive lung process. ILD, pulmonary vascular conditions,
TABLE 3

Results of thoracic imaging for patients presenting with interstitial lung disease and emphysema $(n=10)$

\begin{tabular}{|c|c|c|}
\hline Patient & Radiograph & Computed tomography scan \\
\hline 1 & $\begin{array}{l}\text { Peripheral and basilar } \\
\text { coarse reticular markings }\end{array}$ & $\begin{array}{l}\text { Centrilobular and paraseptal } \\
\text { emphysema. Peripheral interstitial } \\
\text { fibrosis and honeycombing }\end{array}$ \\
\hline 2 & $\begin{array}{l}\text { Coarse reticular markings, } \\
\text { predominantly } \\
\text { peripherally. Enlarged } \\
\text { cardiac silhouette with } \\
\text { prominent pulmonary } \\
\text { artery }\end{array}$ & $\begin{array}{l}\text { Low lung volumes. Bibasilar, } \\
\text { subpleural reticular changes with } \\
\text { traction bronchiectasis. Paraseptal } \\
\text { and centrilobular emphysema. } \\
\text { Enlarged main pulmonary artery }\end{array}$ \\
\hline 3 & $\begin{array}{l}\text { Coarse reticular markings, } \\
\text { predominantly } \\
\text { peripherally }\end{array}$ & $\begin{array}{l}\text { Fibrotic changes throughout both } \\
\text { lungs, with a basilar predominance, } \\
\text { associated with honeycombing and } \\
\text { interseptal thickening. } \\
\text { Emphysematous changes }\end{array}$ \\
\hline 4 & $\begin{array}{l}\text { Lungs hyperinflated. } \\
\text { Prominent diffuse } \\
\text { bronchovascular } \\
\text { markings }\end{array}$ & $\begin{array}{l}\text { Extensive calcified mediastinal } \\
\text { lymphadenopathy with perilymphatic } \\
\text { pulmonary nodules, in keeping with } \\
\text { coal workers pneumoconiosis }\end{array}$ \\
\hline 5 & $\begin{array}{l}\text { Basilar interstitial markings. } \\
\text { Large subpleural bullae, } \\
\text { normal lung volumes }\end{array}$ & $\begin{array}{l}\text { Extensive emphysematous changes. } \\
\text { Enlarged pulmonary arteries. } \\
\text { Honeycomb cysts peripherally and } \\
\text { basally }\end{array}$ \\
\hline 6 & $\begin{array}{l}\text { Peripheral, basilar coarse } \\
\text { reticular markings with } \\
\text { reduced lung volumes }\end{array}$ & $\begin{array}{l}\text { Peripheral coarse increased interstitial } \\
\text { markings. Two large AP window } \\
\text { lymph nodes, largest } 2.1 \mathrm{~cm} \times 1.0 \mathrm{~cm}\end{array}$ \\
\hline 7 & $\begin{array}{l}\text { Basilar coarse interstitial } \\
\text { markings, with large bulla }\end{array}$ & $\begin{array}{l}\text { Hyperinflated lungs. Peripheral and } \\
\text { basilar increased interstitial markings } \\
\text { with early honeycombing }\end{array}$ \\
\hline 8 & $\begin{array}{l}\text { Hyperinflated lungs with } \\
\text { bullous disease. Enlarged } \\
\text { pulmonary artery }\end{array}$ & $\begin{array}{l}\text { Extensive bullous formation. } \\
\text { Interstitium with increased densities, } \\
\text { especially right base }\end{array}$ \\
\hline 9 & $\begin{array}{l}\text { Coarsened interstitial } \\
\text { markings, peripheral and } \\
\text { basilar predominance }\end{array}$ & $\begin{array}{l}\text { Bibasilar fibrotic change with traction } \\
\text { bronchiectasis. Centrilobular } \\
\text { emphysematous changes }\end{array}$ \\
\hline 10 & $\begin{array}{l}\text { Hyperinflation, apical } \\
\text { fibrosis, left upper lobe } \\
\text { nodular disease }\end{array}$ & $\begin{array}{l}\text { Bibasilar fibrosis with honeycombing. } \\
\text { Emphysematous changes. Prominent } \\
\text { pulmonary vasculature }\end{array}$ \\
\hline
\end{tabular}

AP Aortopulmonary

carbon monoxide exposure or anemia explain most of the remaining cases. Chest CT is the critical test for the diagnosis of combined ILD and emphysema. Normal lung volumes do not exclude diagnosis of an intraparenchymal restrictive lung disease in patients with emphysema.

\section{REFERENCES}

1. Cockcroft DW, Fisher KL. Near normalization of spirometry in a subject with severe emphysema complicated by amiodarone lung. Respir Med 1999;93:597-600.

2. Yernault JC, de Jonghe M, de Coster A, Englert M. Pulmonary mechanics in diffuse fibrosing alveolitis. Bull Physiopathol Respir 1975;11:231-44.

3. MacNee W. Pathogenesis of chronic obstructive pulmonary disease. Proc Am Thorac Soc 2005;2:258-66

4. Aduen JF, Zisman DA, Mobin SI, et al. Retrospective study of pulmonary function tests in patients presenting with isolated reduction in single-breath diffusion capacity: Implications for the diagnosis of combined obstructive and restrictive lung disease. Mayo Clin Proc 2007;82:48-54.

5. Mori H, Okubo M, Okamura M, et al. Abnormalities of pulmonary function in patients with non-insulin-dependent diabetes mellitus. Intern Med 1992;31:189-93. 
6. Brussel T, Matthay MA, Chernow B. Pulmonary manifestations of endocrine and metabolic disorders. Clin Chest Med 1989;10:645-53.

7. Forman JW, Ayers LN, Miller WC. Pulmonary diffusing capacity in chronic renal failure. Br J Dis Chest 1981;75:81-7.

8. Garcia JG, Griffith DE, Williams JS, Blevins WJ, Kronenberg RS. Reduced diffusing capacity as an isolated finding in asbestos- and silica-exposed workers. Chest 1990;98:105-11.

9. Wiggins J, Strickland B, Turner-Warwick M. Combined cryptogenic fibrosing alveolitis and emphysema: The value of high resolution computed tomography in assessment. Respir Med 1990;84:365-9.

10. Cottin V, Nunes H, Brillet PY, et al. Combined pulmonary fibrosis and emphysema: A distinct underrecognised entity. Eur Respir J 2005;26:586-93.

11. Mercer BA, Wallace AM, Brinckerhoff CE, et al. Identification of a cigarette smoke-responsive region in the distal MMP-1 promoter. Am J Respir Cell Mol Biol 2009;40:4-12.
12. Selman M. The spectrum of smoking related interstitial lung disorders: The never ending story of smoke and disease. Chest 2003;124:1185-7.

13. Kitaguchi Y, Fujimoto K, Hanaoka M, Kawakami S, Honda T, Kubo K. Clinical characteristics of combined pulmonary fibrosis and emphysema. Respirology 2009;15:265-71.

14. Daniil Z, Koutsokera A, Gourgoulianis K. Combined pulmonary fibrosis and emphysema in patients exposed to agrochemical compounds. Eur Respir J 2006;27:434.

15. Mejia M, Carrillo G, Rojas-Serrano J, et al. Idiopathic pulmonary fibrosis and emphysema: Decreased survival associated with severe pulmonary arterial hypertension. Chest 2009;136:10-15.

16. Brillet P, Cottin V, Letoumelin P, et al. Combined apical emphysema and basal fibrosis syndrome (emphysema/fibrosis syndrome): CT imaging features and pulmonary function tests. J Radiol 2009;90:43-51. 


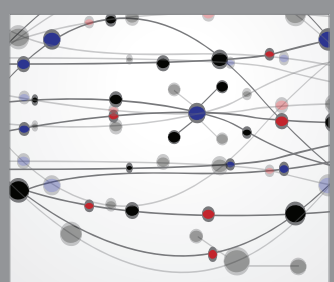

The Scientific World Journal
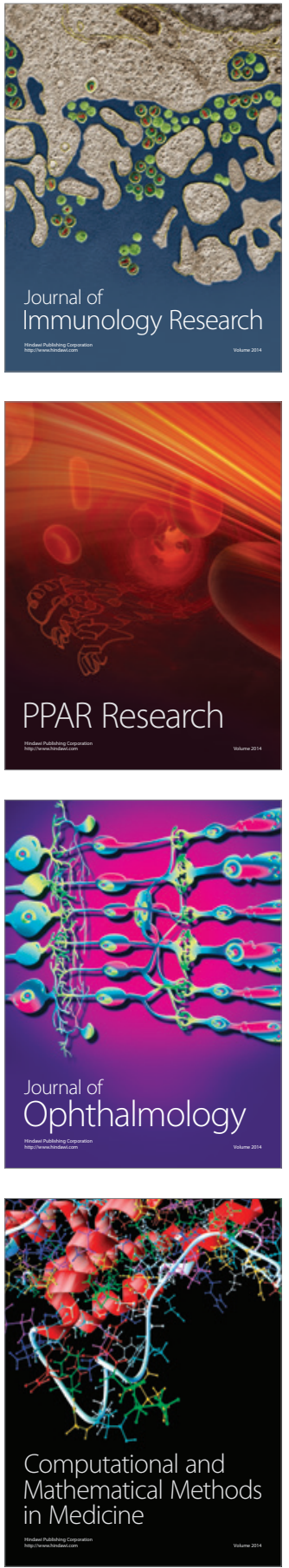

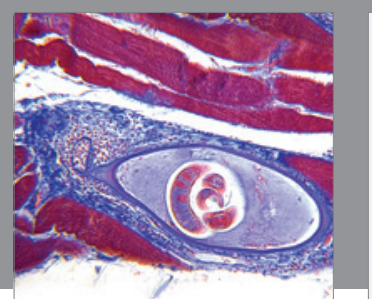

Gastroenterology Research and Practice

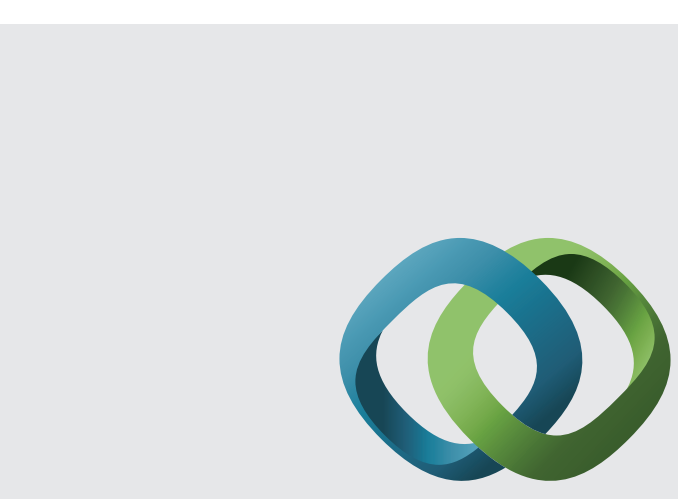

\section{Hindawi}

Submit your manuscripts at

http://www.hindawi.com
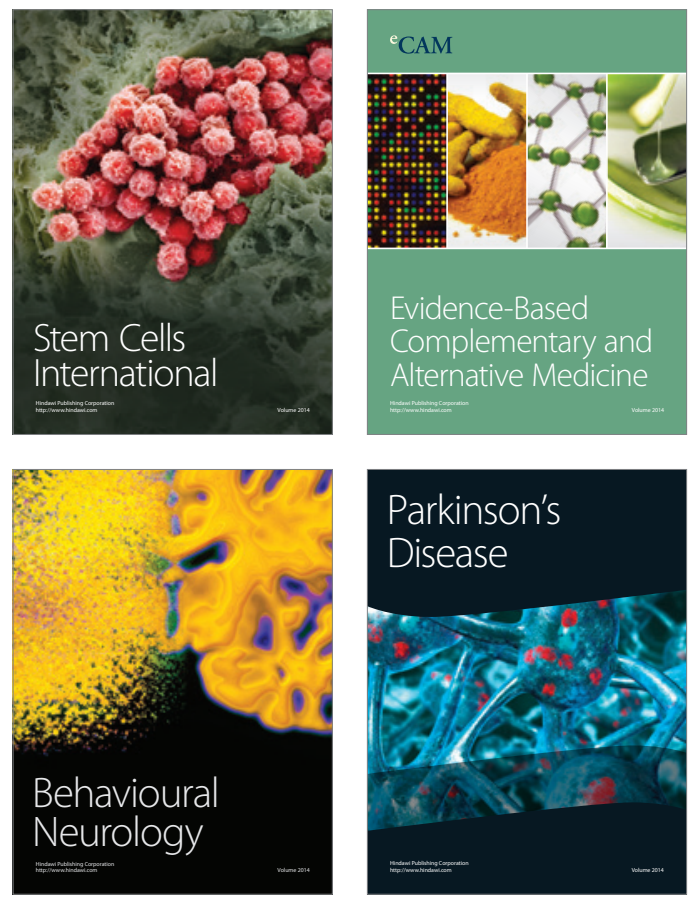
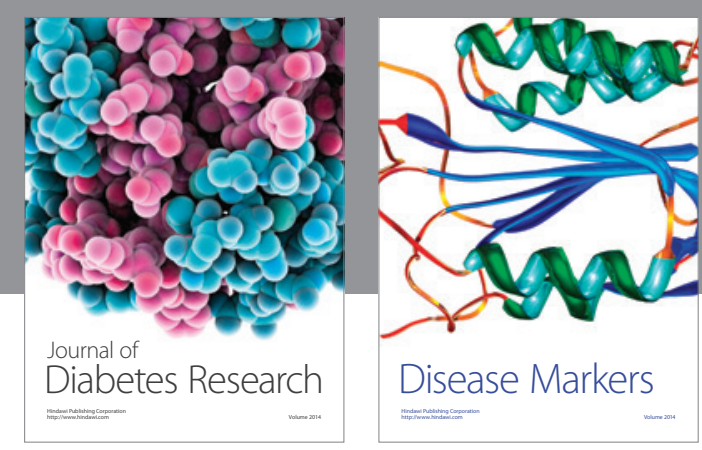

Disease Markers
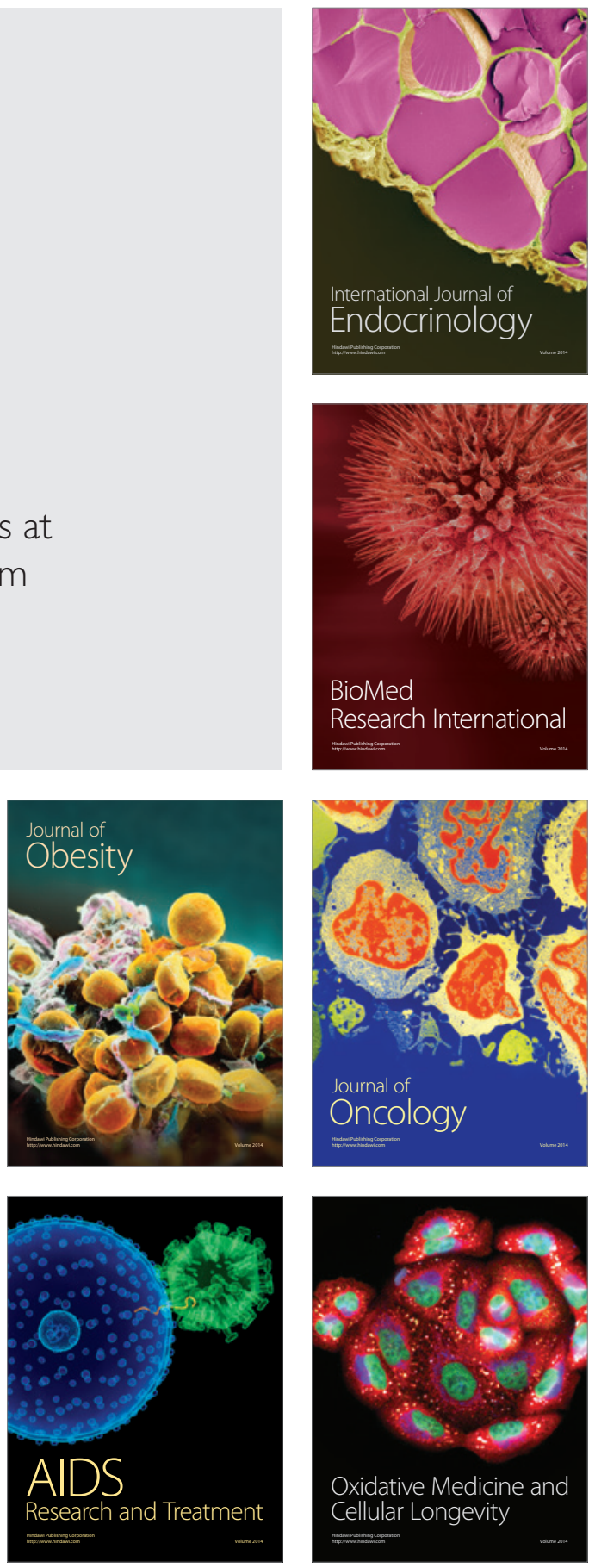